\title{
Socio-demographic determinants of the acceptance of systemic connective tissue diseases
}

\author{
Grażyna Puto ${ }^{1}$, Iwona Repka ${ }^{1}$, Patrycja Zurzycka ${ }^{1}$, Urszula Kowalska \\ ${ }^{1}$ Clinical Nursing Unit, Institute of Nursing and Midwifery, Faculty of Health Sciences, Jagiellonian University Medical College, Krakow, \\ Poland \\ ${ }^{2}$ Long-term Care Facility, Krakow, Poland
}

\begin{abstract}
Introduction: Socio-demographic forecasts indicate a stable increase in the population of elderly people, which gives rise to the need to examine the relationship between the acceptance of chronic illness and socio-demographic variables not only in terms of subjective negative emotions but also because of possible social consequences. The acceptance of a chronic disease is determined by factors related to its character including its severity and the discomfort it brings about but also by factors connected with the patient that is socio-demographic determinants. Objective: The objective of the study was to examine the relationship between socio-demographic variables and the acceptance of a chronic disease of locomotive organs.

Material and methods: The study was conducted in the group of 150 patients diagnosed with a systemic connective tissue disease during its stable phase. A socio-demographic questionnaire as well as a standardised Acceptance of Illness Scale (AIS) adapted by Juszczyński were applied in the study. The study was conducted in accordance with the recommendations of the Declaration of Helsinki. Results: In the group of 150 patients suffering from a systemic connective tissue disease the percentage of women was higher than the percentage of men $(60.7 \%$ vs. $39.3 \%)$. The indicator of the acceptance of illness in the group examined reached $24.5 \pm 7.5$. The strongest correlation was found between the acceptance level and married probants (eta $=0.26 ; p=0.01$ ), high education (eta $=$ $0.24 ; p=0.04)$ and working activity (eta $=0.20 ; p=0.01$ ).

Conclusions: Socio-demographic factors which determine the level of illness acceptance include age, marital status, education and the source of income. The acceptance of illness in the examined group of patients with systemic connective tissue diseases reached 24.5.
\end{abstract}

Key words: systemic connective tissue disease, acceptance of illness, socio-demographic determinants.

\section{Introduction}

Systemic connective tissue diseases (SCTD) are a group of disorders involving the connective tissue which means all structures of joints (bones, cartilage, bone marrow), muscles, and skin but also may affect all systems and organs including the eyes, heart, lungs, kidneys, gastrointestinal tract, and blood vessels. Systemic connective tissue diseases as for e.g. rheumatoid arthritis, lupus erythematosus or systemic sclerosis are chronic diseases in which periods of exacerbation and remission may occur and require pharmacological treatment, rehabilitation and regular rheumatologic control. Although no consensus has been reached as far as the definition of chronic diseases is concerned, their typical feature is slow progress which leads to irreversible changes, which damage the organism and permanently decrease its efficiency and functional ability [1].

The common characteristic of all these diseases is their life-long incurability, which means that they require intensive treatment in the period of their exacer- 
bation and what comes to the fore in the period of their remission is patients' healthy lifestyle, proper rehabilitation and, with time, care provided by other people [1, 2].

Systemic connective tissue diseases (SCTD) lead to complex consequences which refer to various functional areas and give rise to growing physical and psychological discomfort resulting from pain and suffering experienced by patients and progressing limitations or loss of functional abilities [1].

The acceptance of illness means adopting a positive outlook and attitude towards a given situation, and thus, it encourages patients to mobilize their vitality in order to prevent their quality of life from decreasing as a consequence of a chronic disease. The level of acceptance is believed to be determined by factors such as character of the disease including its severity and the discomfort it brings about but also by factors connected with the patient that is socio-demographic determinants [3-6].

\section{Objective}

The objective of the study was to examine the degree of acceptance of illness (AI) and correlation between $\mathrm{Al}$ and socio-demographic variables and disease duration in group of patients with connective tissue diseases.

\section{Material and methods}

The study was conducted between November 2016 and February 2017 in a group of patients undergoing medical treatment in a rheumatology outpatient clinic in Limanowa. Before giving conscious consent for participation in the research every patient was informed about the objective of the study and during the study itself the patient could ask the researcher, who was completing the questionnaire, for any clarifications. The criteria for including patients into the study was diagnosis of rheumatoid arthritis, systemic lupus erythematosus, systemic sclerosis. The patients qualified for the research had been in stable stage of the disease. A socio-demographic questionnaire as well as a standardized questionnaire were applied in this study. The study was approved by Ethics Committee.

The level of illness acceptance was evaluated by means of Acceptance of Illness Scale (AIS) adapted to Polish standards by Juszczyński [7]. The scale consists of eight statements describing negative consequences of bad health conditions referring to: limitations caused by the illness (1), inability to perform certain tasks (2), the sense of being useless (3), dependence on others (4), being a burden for one's relatives and friends (5), a sense of inferiority (6), lack of self-reliance (7) and, consequently, a lowered self-esteem (8). Every statement is assigned a 5-degree scale (from 1 - I definitely agree to
5 - I definitely disagree) and the total score (ranging from 8 to 40) is the general evaluation of the level of illness acceptance (acceptance of the current health condition).

A low result (between 8-18 points of AIS) means lack of acceptance of the illness and adaptation to the current health condition accompanied by a strong sense of psychological discomfort, whereas a high result means the acceptance of one's health condition, which is characterized by lack of negative emotions connected with the illness [7]. In the case of the AIS result in the range 19-29, acceptance of the disease is considered moderate and AIS > 29 indicates a high acceptance of the disease [7].

The analysis of quality variables was described by means of absolute values in particular categories $(\mathrm{N})$ and their percentage participation in the variable distribution (\%). Average variable values with regular distribution were described by means of standard deviation. Relations between quality variables were presented by means of cross tables. The analysis of statistical significance of these relations was carried out by means of a $\chi^{2}$ test when the expected values in all blanks of the table were higher than 5 , otherwise, for $2 \times 2$ table sizes Fisher's test was applied. The comparison of average values of variables with regular distribution in two independent groups was conducted by means of Student's t-test for independent groups and in the case of more than two independent groups by means of ANOVA analysis of variance. In order to evaluate the strength of a relationship between particular variables measured on an interval measurement level Spearman rank-order correlation coefficient (Rho) was used.

Statistical analysis of study results was carried out by means of IBM SPSS Statistics 24 for Windows. In all conducted analyses the level of statistical significance for possible differences and the strength of relations between variables was set at $p<0.05$.

\section{Results}

In the group of 150 patients diagnosed with a SCTD who participated in this study, the percentage of women was slightly higher in comparison with the percentage of men (60.7\% vs $39.3 \%$ ). The average age of women was significantly higher ( 58.5 years \pm 14.1$)$ than the average age of men (51.8 years $\pm 13.3 ; p=0.004$ ). A detailed socio-demographic characteristic is presented in Table I.

The level of acceptance of illness in the examined group reached $24.5 \pm 7.5$, min. 7.5 max. 39; $p$ - NS). A higher level of acceptance of illness was reported in men than in women ( $24.8 \pm 7.2$ vs. $24.4 \pm 7.7$; $p$ - NS; Table II). 
Table I. Socio-demographic characteristic of the group examined

\begin{tabular}{|c|c|c|c|}
\hline \multicolumn{2}{|c|}{ Socio-demographic features } & $n=150$ & $\%$ \\
\hline \multirow[t]{2}{*}{ Gender } & women & 91 & 60.7 \\
\hline & men & 59 & 39.3 \\
\hline \multirow[t]{4}{*}{ Marital status } & married & 96 & 64.0 \\
\hline & single & 19 & 12.7 \\
\hline & divorced & 12 & 8.0 \\
\hline & widowed & 23 & 15.3 \\
\hline \multirow[t]{4}{*}{ Education } & primary & 12 & 8.0 \\
\hline & vocational & 52 & 34.7 \\
\hline & secondary & 59 & 39.3 \\
\hline & higher & 27 & 18.0 \\
\hline \multirow[t]{2}{*}{ Place of residence } & city & 66 & 44.0 \\
\hline & country & 84 & 56.0 \\
\hline \multirow[t]{3}{*}{ Living conditions } & single & 26 & 17.3 \\
\hline & couple & 88 & 58.6 \\
\hline & family & 36 & 24.0 \\
\hline \multirow[t]{3}{*}{ Source of income } & pension & 58 & 38.7 \\
\hline & work & 82 & 54.7 \\
\hline & other & 10 & 6.6 \\
\hline
\end{tabular}

$N$ - number of respondent

The analysis of Spearman rank-order correlation coefficient ( $r h o$ ) in the group examined proved a negative correlation between age and the acceptance of illness (gradually, the acceptance of the disease decreases with age), this results was shown in Table III.

When dividing the examined group in terms of gender, it was shown thatthere is a negative correlation between age of women and the acceptance of illness

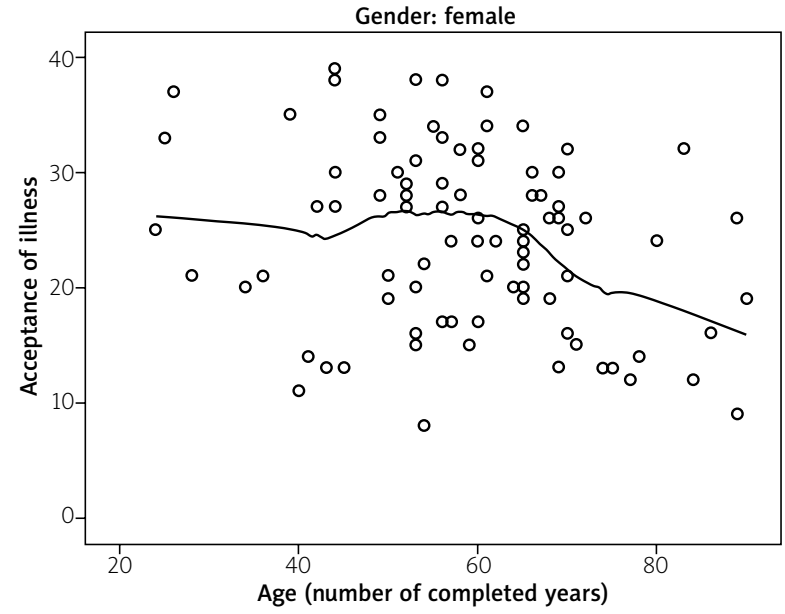

Fig. 1. Acceptance of illness (AIS) in the female group determined by their age.
Table II. Relationship between acceptance of illness (AIS) and gender

\begin{tabular}{|cccccc|}
\hline Gender & Average & SD & Min. & Max. & $p$ \\
\cline { 1 - 5 } Women & 24.4 & 7.7 & 8 & 39 & NS \\
\cline { 1 - 4 } Men & 24.8 & 7.2 & 9 & 38 & \\
\hline
\end{tabular}

SD - standard deviation; NS - statistically insignificant

Table III. Spearman rank-order correlation between the acceptance of illness and socio-demographic variables

\begin{tabular}{|ccc|}
\hline \multicolumn{2}{|c|}{ Socio-demographic variables } & Acceptance of illness \\
\hline Age & Rho & -0.22 \\
\cline { 2 - 3 } & $p$ & 0.00 \\
\hline
\end{tabular}

Rho-Spearman rank-order correlation coefficient; $p-\chi^{2}$ test value

(rho $=-0.23, p=0.02$ ) - Figure 1 , and in the group of men, despite the existing similar tendency, however, no significance was demonstrated ( $r h o=-0.15, p=0.246$; Fig. 2).

The analysis concerning the duration of a SCTD showed that the highest number of patients suffered from the disease for more than 10 years (38.7\%), the duration between 6 and 10 years was reported in 28.0\% of the patients, for the lowest number of patients the duration of the disease ranged between 2 and 5 years (16\%) and the percentage of those whose disease lasted a year reached $17.3 \%$. The highest average acceptance of illness was discovered among the patients whose illness lasted between 6 and 10 years and the lowest in the case of those who suffered from the disease for more than 10 years. Interestingly there was no significant relation between the acceptance of illness (AIS) and the duration of SCTD which results were presented in Table IV.

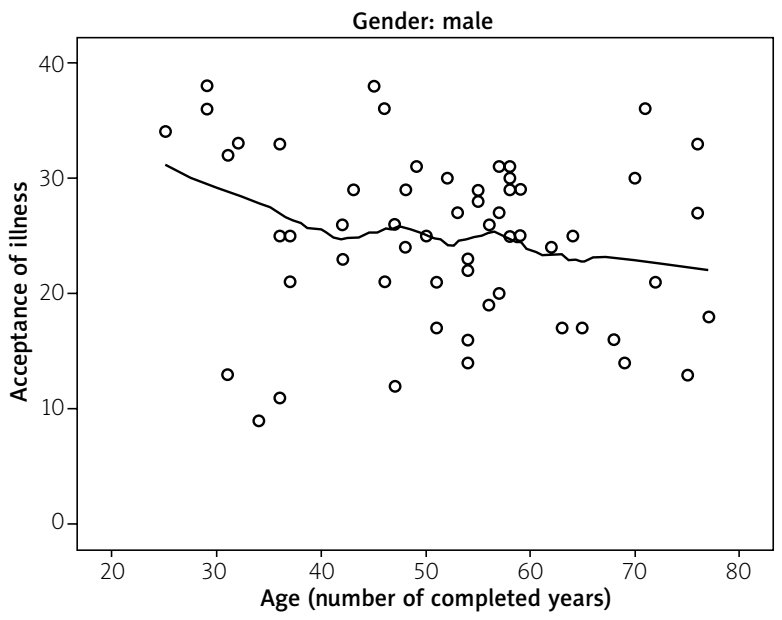

Fig. 2. Acceptance of illness (AIS) in the male group determined by their age. 
Table IV. Relation between acceptance of illness (AIS) and the duration of a systemic connective tissue disease

\begin{tabular}{|lccccc|}
\hline Duration of systemic connective tissue disease & Average & SD & Min. & Max. & $p$ \\
A year & 24.4 & 8.3 & 8 & 38 & NS \\
\hline Between 2 and 5 years & 24.0 & 8.0 & 9 & 39 \\
\hline Between 6 and 10 years & 25.6 & 6.3 & 14 & 38 \\
\hline More than 10 years & 24.1 & 7.8 & 9 & 38 \\
\hline
\end{tabular}

SD - standard deviation; NS - statistically insignificant; $p$ - ANOVA p-value

Table V. Results for particular statements of Acceptance of Illness Scale (AIS)

\begin{tabular}{|c|c|c|c|c|}
\hline Statement & Average & SD & Min. & Max. \\
\hline I have trouble with adapting to the limitations caused by the illness. & 2.5 & 1.3 & 1 & 5 \\
\hline Due to my health condition I cannot do what I like doing. & 2.6 & 1.4 & 1 & 5 \\
\hline The illness sometimes makes me feel useless. & 3.3 & 1.5 & 1 & 5 \\
\hline My health problems make me more dependent on others than I would like to be. & 2.9 & 1.4 & 1 & 5 \\
\hline The illness makes me a burden for my relatives and friends. & 3.7 & 1.4 & 1 & 5 \\
\hline My health condition makes me feel inferior. & 3.3 & 1.5 & 1 & 5 \\
\hline I will never be as much self-reliant as I would like to be. & 2.8 & 1.4 & 1 & 5 \\
\hline $\begin{array}{l}\text { I think that people who spend time with me often feel embarrassed because } \\
\text { of my illness. }\end{array}$ & 3.6 & 1.4 & 1 & 5 \\
\hline
\end{tabular}

SD - standard deviation

The highest number of respondents showed a medium level of the acceptance of illness (49.3\%; 19-29 points), a slightly lower number - a high level of acceptance $(28.0 \%$; 30-40 points) and the lowest number showed a low level of acceptance (22.7\%; 8-18 points).

Average values for particular statements concerning the acceptance of illness indicated that, taking into consideration all aspects of the acceptance of illness, the aspect which the respondents scored the highest was the sense of being a burden for one's relatives and friends (3.7), the sense of embarrassment caused by the disease (3.6) and the awareness of lack of self-reliance, whereas the lowest average value was observed for the sense of discomfort provoked by adapting to the limitations caused by the disease (2.5) and the awareness that due to one's health condition one is not able to do what they like doing (2.6) (Table V).

\section{Discussion}

Illness is a difficult and stressful situation in everybody's life, especially if it is a SCTD which entails changes in everyday routines resulting from limitations in physical fitness and changes in psychological and social functioning.

The results of the individual study conducted in a group of patients suffering from a SCTD, which define the level of acceptance of illness as a moderate one (24.5), correspond to the results of other researches on the acceptance of illness conducted in groups of patients suffering from rheumatoid arthritis (25) [9], or the condition following hip replacement surgery (23.65) [10].

The results comparable to the results of individual study within particular areas of the acceptance of illness were obtained also in the study carried out by Kurowska [10] in a group of patients after hip replacement surgery. The average of particular statements concerning the acceptance of illness proved that, taking into consideration all aspects of the acceptance, respondents, just like in the individual study, scored the highest the sense of being a burden for one's relatives and friends (3.7 vs. 3.7 in individual study), then the sense of embarrassment caused by the disease (3.5 vs. 3.6 in individual study) and the awareness of lack of desired self-reliance (3.1 vs. 3.3 in individual study), whereas the lowest average value was observed for the sense of discomfort provoked by adapting to the limitations caused by the disease (2.6 vs. 2.5 in individual study) and the awareness that due to one's health condition one is not able to do what they like doing (2.16 vs. 2.6 in individual study).

The evaluation of the influence of socio-demographic variables on the acceptance of a SCTD which was conducted in this study proved that the level of acceptance had a tendency to decrease with the respondents' age. Women had more difficulty with adapting to their condition. Lower level of acceptance in women was also discovered in the studies conducted by Łatka et al. [11] in a group of hemodialysis patients, in which the age did 
not have a significant influence on the level of acceptance. However, age had such an influence in the study carried out by Kupcewicz et al. [12] in patients suffering from a chronic obstructive pulmonary disease (COPD). Moreover, opposite to our study, men reported a lower level of acceptance of illness than women. This situation may be explained by the fact that men more often suffer from COPD than women in contrast to the SCTD $[13,14]$.

According to presented study an important determinant of the AIS was marital status. The highest acceptance of illness was discovered in divorced patients and the lowest in widows and widowers. Moczydłowska et al. [15] showed similar conclusions, which proves that the acceptance of illness is the lowest in widowed patients.

The factors which modified the acceptance of systemic connective tissue disease proved to be the level of education as the rising level of education in the study was accompanied by rising acceptance of a connective tissue disease. A positive influence of the level of education, place of residence, work and positive opinion about one's financial status was also confirmed in Łatka et al. [11], study in a group of hemodialysis patients. Authors proved that the rising level of education was accompanied by rising acceptance of illness and living in a city was connected with higher acceptance of illness. Moreover, the results of the study indicate that patients who considered their financial status to be satisfying or those depending on their relatives for money had a higher level of acceptance than pensioners. The influence of education on the level of acceptance of illness was also confirmed in other studies in the case of patients suffering from inflammatory bowel disease [14] or COPD [5] or patients aftertotal hip replacement [10] as well as varicose veins of the lower extremities [16].

The source of income had a significant impact on the level of acceptance of a sCTD $[12,16]$. People in employment were characterized by a higher level of acceptance compared to people living off other sources on income (e.g. pension, retirement, other benefits). However, in the Kupcewicz et al. study [12] the effect of education or place of residence on AIS has not been demonstrated, the Authors confirmed the influence of socio-professional status.

This study did not revealed significant relationship between the duration of a SCTD and the acceptance of illness what correlate with study in a group of patients suffering from COPD [17]. However, in the AIS evaluation study in patients with diabetes mellitus type 2 showed that level of AIS was significantly lower in patients suffering from the disease for more than 10 years [8]. These differences seem to be interesting because both a longterm course of disease like SCTD or diabetes can lead to the occurrence of complications and disability progression. It can be speculated that in the case of diseases like SCTD, the age of onset is lower and compliance of treatment higher than patients with type 2 diabetes who is an older age group than, for example, patients with type 1 diabetes [18].

The aforementioned results of presented study and the studies conducted by other researchers indicate that the AIS influenced by numerous clinical and socio-demographic factors such as age, gender, financial status or level of education. The presented study does not differentiate patients with RA, SLE or SSc which may constitute a limitation of this study, but on the other hand allows for a broader view on the patient's acceptance of such significant systemic diseases.

Including measurement of AIS into everyday clinical practice allow to facilitate cooperation with the patient and allows stratification of patients with SCTD requiring specific support from specialists like a psychologist or psychotherapist.

\section{Conclusions}

The acceptance of illness in the examined group of patients suffering from a SCTD depends on socio-demographic factors such as: age, marital status, education and the source of income.

In the examined group no significant relationship was found between the duration of a SCTD and the acceptance if illness.

The authors declare no conflict of interest.

\section{References}

1. Markocka-Mączka K, Grabowski K, Taboła R. Choroby przewlekłe - problem XXI wieku. In: Dobrostan a edukacja. Dybińska E, Zboina B (eds.). NeuroCentrum, Lublin 2016; 77-186.

2. Topór-Mądry R. Choroby przewlekłe. Obciążenie, jakość życia i konsekwencje ekonomiczne. Zdrowie Publiczne i Zarządzanie 2011; 9: 25-49.

3. Mazurek J, Lurbiecki J. Skala akceptacji choroby przewlekłej i jej znaczenie w praktyce klinicznej. Pol Merk Lek 2014; 36: 106-108.

4. Martynow A, Lefek K, Wierzbicka B, et al. Wpływ akceptacji choroby na dostosowanie się do zaleceń terapeutycznych chorych z migotaniem przedsionków. J Edu Health Sport 2017; 7: $154-170$

5. Jankowska-Polańska B, Kasprzyk M, Chudiak A, et al. Relation between illness acceptance and quality of life in patients with chronic obstructive pulmonary disease (COPD). Pneumonol Alergol Pol 2016; 84: 3-10.

6. Kamińska M, Pawlak-Warszawska A, Baczewska B, et al. Efficiency of patients with carcinoma and acceptance of the disease. Stud Med 2014; 30: 6-13. 
7. Juczyński Z. Narzędzia pomiaru w promocji i psychologii zdrowia. Pracownia Testów Psychologicznych. Warszawa 2009, 162-166.

8. Kurowska K, Lach B. Akceptacja choroby i sposoby radzenia sobie ze stresem $u$ chorych na cukrzycę typu 2. Diabetol Prakt 2011; 12: 113-119.

9. Wróbel A, Majda A. Religijność i akceptacja choroby wśród pacjentów z reumatoidalnym zapaleniem stawów. Problemy Pielęgniarstwa 2015; 23: 220-226.

10. Kurowska K, Rumińska B. Akceptacja choroby i sposoby radzenia sobie ze stresem u osób po wszczepieniu endoprotezy stawu biodrowego. Pielęg Chir Angiol 2011; 4: 203-210.

11. Łatka J, Majda A, Sołtys A. Uwarunkowania akceptacji choroby przez chorych poddawanych hemodializie zewnątrzustrojowej. Problemy Pielęgniarstwa 2013; 21: 318-326.

12. Kupcewicz E, Abramowicz A. Wpływ wybranych czynników socjodemograficznych na stopień akceptacji choroby i poziom satysfakcji z życia u pacjentów leczonych z powodu przewlekłej obturacyjnej choroby płuc. Probl Hig Epidemiol 2015; 5: $142-148$.

13. Rycroft CE, Heyes A, Lanza L, Becker K. Epidemiology of chronic obstructive pulmonary disease: a literature review. Int J Chron Obstruct Pulmon Dis 2012; 7: 457-494.

14. Aryal S, Diaz-Guzman E, Mannino DM. Influence of sex on chronic obstructive pulmonary disease risk and treatment outcomes. Int J Chron Obstruct Pulmon Dis 2014; 9: 1145-1154.

15. Moczydłowska A, Krajewska-Kułak E, Kózka M, et al. Stopień akceptacji choroby przez pacjentów oddziałów zachowawczych i zabiegowych. Pielęg Chir Angiol 2014; 2: 62-70.

16. Wiśniewska-Szumacher A, Karakiewicz B, Bażydło $M$, et al Czynniki determinujące akceptację choroby przez pacjentów leczonych z powodu żylaków kończyn dolnych. Problemy Pielęgniarstwa 2013; 21: 489-495.

17. Glińska J, Grzegorczyk A, Dziki Ł, et al. Proces adaptacji do życia z nieswoistymi chorobami zapalnymi jelit. Problemy Pielęgniarstwa 2015; 23: 7-12.

18. Bień A, Rzońca E, Kańczugowska A, Iwanowicz-Palus G. Factors affecting the quality of life and the illness acceptance of pregnant women with diabetes. Int J Environ Res Public Health 2016; 13: 68 